\title{
ON FUNDAMENTALS OF PHILOSOPHICAL PSYCHIATRY
}

\author{
E. Neu1, M.C. Michailov1, C. Lütge2, P. Birkenbihl1, S.K. Gupta3, M. Kaune-Sharma3, \\ M. Schratz4, G. Weber5
}

1 Inst. Umweltmedizin c/o ICSD e.V., Pharmaco-Physiology, Munich, Germany.

2 Techn. Univ. Muenchen, Inst.Ethics Dir., Munich, Germany.

3 All India, Inst. Med. Sci., New Delhi, India.

4 Univ. Innsbruck, School Education Dean, Innsbruck, Austria.

5 Univ. Luxembourg\&Vienna, Fac. Psychology Dean, Vienna, Austria.

"There is but one safe way to avoid mistakes: to do nothing or, at least to avoid something new: This, however, in itself, may be the greatest mistake of all."

(Albert von SZENT-GYÖRGYI*, Nobel-Price for vitamin $C$ and bio-catalysis, in Bioenergetics: Foreword, 1957). Honorary ICSDMember

INTRODUCTION: Philosophy is regina scientiarum considering all sciences (Immanuel KANT) reflected by epistemology-ethicsaesthetics. Central position of psychiatry in medicine, psychology, sociology needs creation of philosophical psychiatry including not only moral philosophy, but also scientific-theory, metaphysics, etc. Fundamental question "what is the human?" (Kant) needs future research - anthropology (Table).

\section{CONCEPTION:}

A. EPISTEMOLOGY. An integrative psychiatry needs enlarged fundamentals in normal\&pathological neurophysiology/morphology/-genetics, psycho-neurology (e.g. psycho-neuroimmunomodulation), psychosomatics (Th.v.UEXKÜLL) and somatopsychics (Y.IKEMI) related to psychopathology. An integrative psycho-neuro-therapy incl. Chinese-Indian\&other traditional-medicine in education\&treatment has to be discussed. Reconsideration of psychologial-psychiatric notions acc. to axiology-logic-semantic is recommendable.

B. MORAL PHILOSOPHY. Independently from various modern ethical-theories (deontology, utilitarism, etc.) has to be considered Kant's human obligations to himself-human medical personnel (a), other humans-patients (b), sub-human, e.g. reduction of animal-experiments (c) suprahuman beings: moral\&scientific frames about applications of theologicalpractices of great-religions for therapy (BrahmanismBuddhism/Christianism-Mosaism/ConfucianismTaoism/Mohammedanism).

\section{AESTHETICS. In relation to A-B interdisciplinary} consideration is necessary to destine volume of paradigmchanges in psychiatry (\& neurology) by non- \& surgical therapies, leading to pathophysiological \& psychopathological effects (primum non nocere) (Fig. Lexicon).

CONCLUSION: Establishment of regular common congresssessions of EPA/WPA with philosophical (FISP-ISB-EACME, etc.)/psychological (IUPsyS, etc.)/neurological (WFN)/physiological (IUPS,etc.)/medical societies (ISIM-ICC-FIGO-SIU-etc.) could open new scientific\&political dimension in medicine, leading to humanization, higher efficacy \& internationalization of science-medicine-ecology. Foundation of an International Academy for Psychiatry (IAP) (similar to Eur.Acad.Neurol. (EAN2015-Berlin, 1st Congress) could support an integrative psychiatry (A-C) in context of UNO-Agenda21 for better healtheducation-etc. on global level.

Ref. see Michailov et al., Neu et al. WPA-2019-Lissabon and: Philosophy: World-Congr.-Philos. FISP-2018-Beijing (in-press); -2013-Athens Abstr.Book:464-5,503-4,766; -2008-Seoul-Proc.Vol.4: 101-108;195-214;229-237; -2003-Istanbul:273-281. Philosophy of Law: IVR-2019-Lucerne, AB 114-116; -2015-
Model about

ETHICS IN CONTEXT OF AN INTEGRAL ANTHROPOLOGY

(Related to Human Obligations acc. to Kant and Dimensions acc. to Jannsens)

\begin{tabular}{lll}
\multicolumn{3}{c}{ GENERAL ANTHROPOLOGY } \\
Pedagogical & Philosophical & Medical \\
Educative & Normative & Curative, \\
& & Prophylactic
\end{tabular}

\begin{tabular}{lll}
\multicolumn{3}{c}{ SPECIAL ANTHROPOLOGY } \\
Human Obligations to: & Anthropology: & Human Dimensions: \\
Himself & Individual & A + G + H + X1 \\
Other Human & Social & E + D + X2 \\
Sub-Human & Natural & C + B + X3 \\
Supra-Human (God, etc.) & Supra-Natural & F + X4 (Xn=Varia)
\end{tabular}

Louis Jannsens (Book "European Bioethics", ed. 2007, to Conference Leuven 2006) described 8 dimensions of human person, i.e. relations PERSON

$\begin{array}{llll}\text { A. Subject } & \text { B. Body } & \text { C. Material World } & \text { D. Other Persons }\end{array}$

E. Social World F. God G. Historical Being H. Unique/Equal to others

DEDICATION for long-time moral/scientific support of Profs. K.Lorenz*/Austria, N.Karabaschev, D.Orachovats, M.Rashev, N.Schipkovensky, M.Slivensky, P.S. Stainov/Bulgaria, R.Aron, J.Dausset*, J.-M.Lehn*/France; A.Hewish*, B.Josephson*, Lord A.Todd*/GB; M.Eigen*, H.Michel*, M.Mikorey, Th.\&J.v.Uexküll, C.F.v.Weizsäcker/Germany; G.Govil, H.B.Khorana*, K.Singh/India; K.Fukui*, Y.Ikemi, H.Suematsu/Japan; H.Bethe*, J.Deisenhofer*, D.Hubel $^{*}$, L.Pauling ${ }^{*}$, H.Weiner, R. Wilson*/USA (*Nobel Laureate)

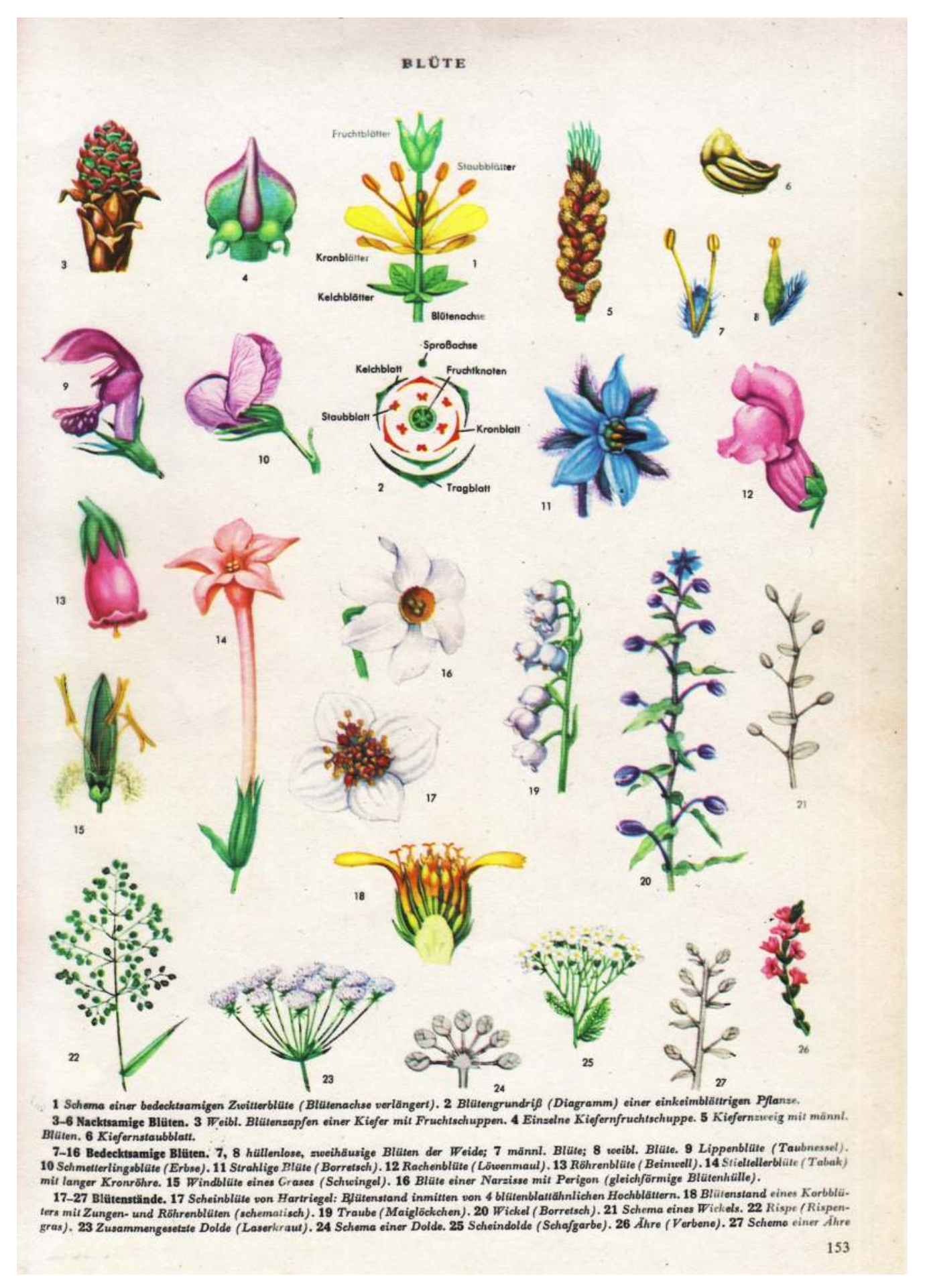

Copyright $@ 2017$ Author Names and Contact Details 